Check for updates

Cite this: RSC Adv., 2019, 9, 21637

\title{
Cobalt, nickel and copper complexes with glycinamide: structural insights and magnetic properties $\dagger$
}

\author{
Darko Vušak, (D) ${ }^{a}$ Neven Smrečki, ${ }^{a}$ Biserka Prugovečki, (DD *a Ivica Đilović, (D) a \\ Inka Kirasić, ${ }^{a}$ Dijana Žilić, (D) ${ }^{\mathrm{b}}$ Senada Muratović ${ }^{\mathrm{b}}$ and Dubravka Matković- \\ Čalogović (D) a
}

\begin{abstract}
Ten new compounds of $\mathrm{Co}, \mathrm{Ni}$ and $\mathrm{Cu}$ with glycinamide $\left(\mathrm{HL}=\right.$ glycinamide): $\left[\mathrm{Co}\left(\mathrm{H}_{2} \mathrm{O}\right)_{2}\left(\mathrm{HL}_{2}\right] \mathrm{Cl}_{2}(1 \mathrm{a})\right.$, $\left.\left[\mathrm{Co}\left(\mathrm{H}_{2} \mathrm{O}\right)_{2}(\mathrm{HL})_{2}\right] \mathrm{Br}_{1.06} \mathrm{Cl}_{0.94}(1 \mathrm{~b}),\left[\mathrm{Co}\left(\mathrm{H}_{2} \mathrm{O}\right)_{2}(\mathrm{HL})_{2}\right]\right]_{2}(1 \mathrm{c})$, $\left[\mathrm{Ni}\left(\mathrm{H}_{2} \mathrm{O}\right)_{2}(\mathrm{HL})_{2}\right] \mathrm{Cl}_{2}(2 \mathrm{a}),\left[\mathrm{Ni}_{(}\left(\mathrm{H}_{2} \mathrm{O}\right)_{2}\left(\mathrm{HL}_{2}\right] \mathrm{Br}_{0.94} \mathrm{Cl}_{1.06}\right.$ (2b), $\left.\left[\mathrm{Ni}\left(\mathrm{H}_{2} \mathrm{O}\right)_{2}(\mathrm{HL})_{2}\right]\right]_{2}$ (low and room temperature polymorph, $2 \mathrm{c}_{\mathrm{LT}}$ and $2 \mathrm{c}_{\mathrm{RT}}$ ), $\left[\mathrm{CuCl}_{2}(\mathrm{HL})_{2}\right](3 a)$, $\left[\mathrm{CuBr}_{1.3} \mathrm{Cl}_{0.7}(\mathrm{HL})_{2}\right](3 \mathrm{~b})$ and $\left\{\left[\mathrm{Cu}(\mathrm{HL})_{2}\right]_{2}\left[\mathrm{Cu}_{2} \mathrm{I}_{6}\right]\right\}_{n}(3 \mathrm{c})$, as well as glycinamide hydroiodide $\left(\mathrm{H}_{2} \mathrm{LI}\right)$ and a new polymorph of glycinamide hydrochloride $\left(\boldsymbol{\beta}-\mathrm{H}_{2} \mathrm{LCl}\right)$ were prepared and characterized by single-crystal $\mathrm{X}-$ ray diffraction, infrared spectroscopy, thermal analysis (TG/DTA) and ESR spectroscopy. 1a, 1b, 2a and $2 b$ are isostructural, as well as $1 c$ and $2 c_{R T}$, while the $\mathrm{Cu}$ compounds $(3 a-c)$ have entirely different molecular structures. All investigated compounds are mononuclear with exception of the 1D coordination polymer $3 \mathrm{c}$. Compound $3 \mathrm{c}$ contains copper ions in the mixed oxidation state $\mathrm{Cu}(\mathrm{I})$ and $\mathrm{Cu}(\mathrm{I})$ with interesting magnetic properties. Paramagnetic behaviour was found in $1 \mathrm{a}, 1 \mathrm{~b}, 3 \mathrm{a}$ and $3 \mathrm{~b}$. Temperature induced polymorphic transformation was observed in $2 \mathrm{c}$. Compounds $1 \mathrm{a}$ and 3 a showed moderate antiproliferative activity and selectivity toward the human breast tumor cell line MCF-7.
\end{abstract}

Received 16th May 2019

Accepted 17th June 2019

DOI: $10.1039 / \mathrm{c} 9 \mathrm{ra0} 6363 \mathrm{~h}$

rsc.li/rsc-advances complexes with ligands analogous to those of amino acids side chains are useful in protein crystallography for interpretation and validation of protein structural data. ${ }^{11-15}$

Amino acids/amino acid derivatives and their metal complexes possess various biological activities such as antiretroviral, ${ }^{16}$ antibacterial and antifungal, ${ }^{17-20}$ and antiproliferative effects on tumor cells, ${ }^{21}$ with potential applications in biomedicine. Copper coordination compounds, especially those with mixed oxidation states, are also of special interest because of their magnetic properties. ${ }^{22-24}$ Cobalt and nickel polynuclear compounds showed interesting ferro- and antiferromagnetic properties, specifically compounds containing the carboxylic group, such as amino acids and their derivatives. ${ }^{24-26}$ There are fewer published papers on magnetic measurements and structural studies of such cobalt and nickel compounds than for copper compounds.

Glycinamide (HL) is the simplest amino acid amide, being cheap, readily available and easily synthesized. In bio-systems its derivative glycinamide ribonucleotide is known as an intermediate in de novo biosynthesis of purine. ${ }^{27}$ Moreover, glycilprolyl-glycinamide and its metabolites (glycine, glycinamide, proline, glycil-proline and prolyl-glicinamide) were tested in vitro as potential HIV-1 replication inhibitors. It was shown that only glycil-prolyl-glycinamide and glycinamide showed a pronounced inhibitory effect. ${ }^{16}$

Glycinamide is capable of building various hydrogen bonding architectures, having four $\mathrm{N}-\mathrm{H}$ hydrogen atoms in the 
neutral form as potential HB-donors and an amide oxygen as the acceptor. In the Cambridge Structural Database (CSD) ${ }^{28}$ there are only six structures containing the glycinamide fragment: glycinamide hydrochloride, ${ }^{29}$ two rhodium complexes, ${ }^{30,31}$ a bimetallic (Mn, Cr) ferrimagnet, ${ }^{32}$ a ruthenium complex $^{33}$ and an iridium complex. ${ }^{34}$ This is surprising because coordination of metal ions by amide groups of simple amides, peptides and proteins is of great interest due to their importance in biological systems. ${ }^{35}$ Different modes of coordination to the metal ion were found. In the reported rhodium(III) complexes glycinamide acts as a monodentate ligand coordinating rhodium through the amine nitrogen atom. In the manganese complex glycinamide acts as a bidentate $\mathrm{N}, \mathrm{O}$ coordinating ligand through the amine nitrogen and amide oxygen atoms, while in the ruthenium and iridium complexes the glycinamidato group acts as a bidentate $N, N^{\prime}$-coordinating ligand through nitrogen atoms from amide and amino groups (Scheme 1).

As a part of our ongoing research on preparation and structural investigation of metal complexes with amino acids and their derivatives, ${ }^{\mathbf{2 1 , 3 6 - 3 9}}$ we have prepared various copper(II) and nickel(II) complexes with $N$-alkyliminodiacetamide. ${ }^{40}$ In order to expand our knowledge on the properties of amino acetamide complexes in the solid state, we report synthesis and solid-state characterization (X-ray structural analysis, IR and ESR spectroscopy, TG/DTA analysis) of cobalt, nickel and copper complexes with glycinamide. Structural characterization of glycinamide hydroiodide $\left(\mathbf{H}_{2} \mathbf{L I}\right)$ and a new polymorph of glycinamide hydrochloride $\left(\boldsymbol{\beta}-\mathbf{H}_{2} \mathbf{L C l}\right)$ is also given. Reactions of $\mathbf{H}_{2} \mathbf{L C l}$ with cobalt(II), nickel(II) and copper(II) halides, acetate or hydroxides yielded ten novel compounds: nine mononuclear $\left[\mathrm{Co}\left(\mathrm{H}_{2} \mathrm{O}\right)_{2}(\mathrm{HL})_{2}\right] \mathrm{Cl}_{2} \quad(\mathbf{1 a}), \quad\left[\mathrm{Co}\left(\mathrm{H}_{2} \mathrm{O}\right)_{2}(\mathrm{HL})_{2}\right] \mathrm{Br}_{1.06} \mathrm{Cl}_{0.94} \quad(\mathbf{1 b})$, $\left[\mathrm{Co}\left(\mathrm{H}_{2} \mathrm{O}\right)_{2}(\mathrm{HL})_{2}\right] \mathrm{I}_{2}(\mathbf{1 c}),\left[\mathrm{Ni}\left(\mathrm{H}_{2} \mathrm{O}\right)_{2}(\mathrm{HL})_{2}\right] \mathrm{Cl}_{2}(\mathbf{2 a}),\left[\mathrm{Ni}\left(\mathrm{H}_{2} \mathrm{O}\right)_{2}(\mathrm{HL})_{2}\right]$ $\mathrm{Br}_{0.94} \mathrm{Cl}_{1.06}(2 \mathbf{b}),\left[\mathrm{Ni}\left(\mathrm{H}_{2} \mathrm{O}\right)_{2}(\mathrm{HL})_{2}\right] \mathrm{I}_{2}$ (low and room temperature polymorphs, $2 \mathbf{c}_{\mathbf{L T}}$ and $\left.2 \mathbf{c}_{\mathbf{R T}}\right),\left[\mathrm{Ni}\left(\mathrm{H}_{2} \mathrm{O}\right)_{2}(\mathrm{HL})_{2}\right] \mathrm{I}_{2}(2 \mathrm{c}) ;\left[\mathrm{CuCl}_{2}(\mathrm{HL})_{2}\right]$ (3a); $\left[\mathrm{CuBr}_{1.3} \mathrm{Cl}_{0.7}(\mathrm{HL})_{2}\right](3 \mathbf{b})$ and a $1 \mathrm{D}$ coordination polymer $\left\{\left[\mathrm{Cu}(\mathrm{HL})_{2}\right]_{2}\left[\mathrm{Cu}_{2} \mathrm{I}_{6}\right]\right\}_{n}(3 \mathbf{c})$.

\section{Results and discussion}

\section{Synthesis and properties of the complex compounds}

Reactions of $\mathbf{H}_{2} \mathbf{L C l}$ with metal halides and sodium bicarbonate were performed in aqueous solutions, and the reactions of $\mathbf{H}_{2}$ LCl with metal hydroxides mechanochemically by neat grinding (NG), Scheme 2. Synthesis of 1c was performed in an aqueous solution by using cobalt(II) acetate and surplus of potassium iodide. When metal bromides were used as reactants mixed halide compounds $\mathbf{1} \mathbf{b}, \mathbf{2} \mathbf{b}$ and $\mathbf{3 b}$ were obtained (bromide ions originated from the metal bromide, while the chloride ions originated from glycinamide hydrochloride). Cobalt(II) and
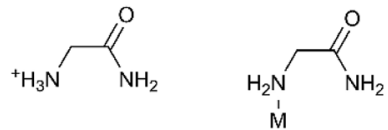

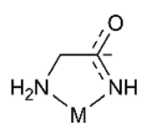

Scheme 1 Structural diagrams of $\mathrm{H}_{2} \mathrm{~L}^{+}$and $\mathrm{HL} / \mathrm{L}^{-}$modes of binding in complexes in the solid state.

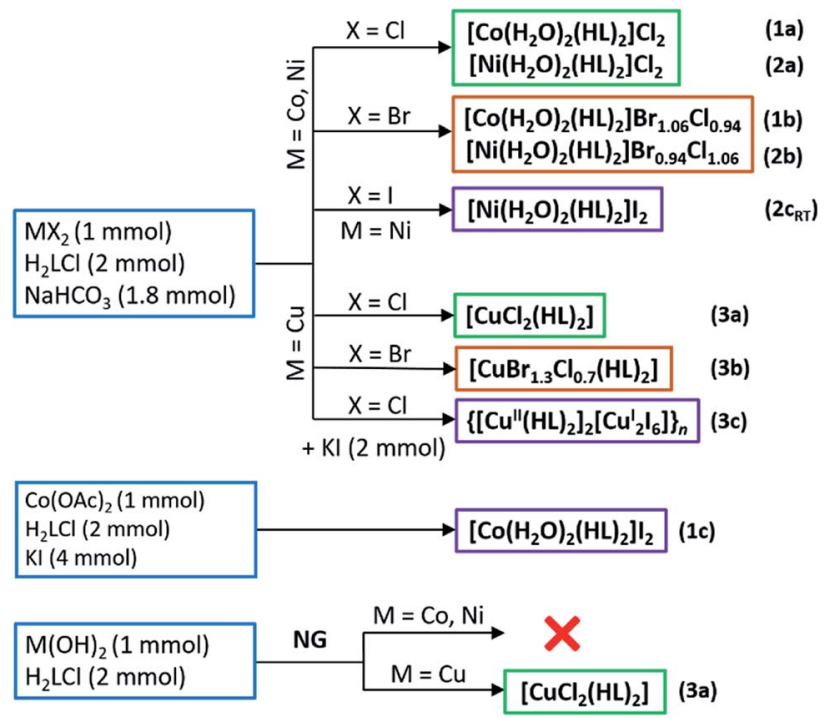

Scheme 2 Preparation of the glycinamide complexes with Co, Ni and Cu.

nickel(II) gave water-soluble compounds $\mathbf{1 a}-\mathbf{c}, \mathbf{2 a}, \mathbf{b}$ and $\mathbf{2} \mathbf{c}_{\mathbf{R T}}$ of the general formula $\left[\mathrm{M}\left(\mathrm{H}_{2} \mathrm{O}\right)_{2}(\mathrm{HL})_{2}\right] \mathrm{X}_{2}(\mathrm{M}=\mathrm{Co}, \mathrm{Ni} ; \mathrm{X}=\mathrm{Cl}, \mathrm{Br} /$ $\mathrm{Cl}, \mathrm{I})$. On the other hand, copper(II) gave different and less soluble compounds $\left[\mathrm{CuX}_{2}(\mathrm{HL})_{2}\right](\mathrm{X}=\mathrm{Cl}, \mathrm{Br} / \mathrm{Cl})$ (3a and $\left.3 \mathbf{b}\right)$. A partial reduction of copper(II) to copper(I) occurred when KI was introduced into the solution of $\mathrm{CuCl}_{2}, \mathbf{H}_{2} \mathbf{L C l}$ and $\mathrm{NaHCO}_{3}$ leading to the formation of a $1 \mathrm{D}$ coordination polymer $\left\{\left[\mathrm{Cu}(\mathrm{HL})_{2}\right]_{2}\left[\mathrm{Cu}_{2} \mathrm{I}_{6}\right]\right\}_{n}(3 \mathbf{c})$. Compound 3a can also be prepared by NG mechanochemical synthesis, using $\mathrm{Cu}(\mathrm{OH})_{2}$ and $\mathbf{H}_{2} \mathbf{L C l}$, offering a very fast and clean route to the desired product (Scheme 2).

All compounds are air-stable. Thermal stability of the cobalt(II) and nickel(II) compounds (1a-c, 2a,b and $\mathbf{2 c}_{\mathbf{R T}}$ ) is characterized by the initial loss of coordinated water molecules in the range $100-120{ }^{\circ} \mathrm{C}$, followed by further decomposition starting between 220 and $265^{\circ} \mathrm{C}$. Copper(II) compounds (3a-c) are less stable than cobalt(II) and nickel(II) compounds and decompose at significantly lower temperatures in the range 160-195 ${ }^{\circ} \mathrm{C}$. Full thermal analyses data are given in Table S1 $(\mathrm{ESI} \dagger)$.

Infrared spectra of the compounds are characterized by the presence of very strong and sharp bands of the carbonyl group stretching, $\nu(\mathrm{C}=\mathrm{O})^{41,42}$ occurring in the range of 1674$1644 \mathrm{~cm}^{-1}$. Comparing the spectra of cobalt(II), nickel(II) and copper(II) complexes with chlorides and bromides, the $\nu(\mathrm{C}=\mathrm{O})$ bands occur at the highest wavenumbers in the spectra of copper(II) complexes. Carbonyl stretching in protonated glycinamide, $\boldsymbol{\beta}-\mathbf{H}_{2} \mathbf{L C l}$, was observed at higher wavenumber then in any of the complexes, at $1688 \mathrm{~cm}^{-1}$, showing weakening of the $\mathrm{C}=\mathrm{O}$ bond upon coordination to the metal ion. The amide II band, ${ }^{\mathbf{4 1}}$ which appears at $1594 \mathrm{~cm}^{-1}$ in the spectrum of $\boldsymbol{\beta}-\mathbf{H}_{2} \mathbf{L C l}$, was found in the similar region in the spectra of all compounds (1570-1600 $\mathrm{cm}^{-1}$ ) and at $1555 \mathrm{~cm}^{-1}$ for compound 3c. The bands of antisymmetric and symmetric stretching of the amide amino groups are observed in the range 3300-3100 $\mathrm{cm}^{-1}$, indicating that these are involved in hydrogen bonding, as evidenced by the crystal structures of all nine complexes. A 
sharp band of medium intensity, which was assigned as $\mathrm{O}-\mathrm{H}$ stretching, $\nu\left(\mathrm{OH}, \mathrm{H}_{2} \mathrm{O}\right)$, was observed at roughly $3430 \mathrm{~cm}^{-1}$ in the spectra of compounds $1 \mathbf{1 a}-\mathbf{c}, \mathbf{2 a - c}$. The band is, of course, absent in the spectra of compounds 3a-c. IR spectra of representative compounds are given in Fig. S1 (ESI $\dagger$ ).

\section{Molecular and crystal structures of $\beta-\mathrm{H}_{2} \mathrm{LCl}$ and $\mathrm{H}_{2} \mathrm{LI}$}

Both $\mathbf{H}_{2} \mathbf{L C l}$ polymorphs crystallize in monoclinic space groups, $\boldsymbol{\alpha}$ in $P 2_{1} / c$ and $\boldsymbol{\beta}$ in $P 2_{1} / m$, while $\mathbf{H}_{2} \mathbf{L I}$ crystallizes in the orthorhombic crystal system, space group Pca2 $2_{1}$ (Table S2, ESI $\dagger$ ). ORTEP drawings of $\boldsymbol{\beta}-\mathbf{H}_{2} \mathbf{L C l}$ and $\mathbf{H}_{2} \mathbf{L I}$ are given in Fig. S2 (ESI $\dagger$ ). Selected bond distances and angles in the crystal structures of $\boldsymbol{\alpha}-\mathbf{H}_{2} \mathbf{L C l},{ }^{29} \boldsymbol{\beta}$ $\mathbf{H}_{2} \mathbf{L C l}$ and $\mathbf{H}_{2} \mathbf{L I}$ are presented in Table S3 (ESI $\dagger$ ). Structures of the $\left[\mathrm{H}_{2} \mathrm{~L}\right]^{+}$ions are different in the two polymorphs: torsion angle N1$\mathrm{C} 1-\mathrm{C} 2-\mathrm{N} 2$ is $149.64(15)^{\circ}$ in $\boldsymbol{\alpha}-\mathbf{H}_{2} \mathbf{L C l}$, and $180^{\circ}$ in $\boldsymbol{\beta}-\mathbf{H}_{2} \mathbf{L C l}$ and $\mathbf{H}_{2} \mathbf{L I}$. In $\boldsymbol{\alpha}-\mathbf{H}_{2} \mathbf{L C l}$, centrosymmetric $\left[\mathrm{H}_{2} \mathrm{~L}\right]^{+}$dimers [graph-set $R_{2}{ }^{2}(10)$ ] are bridged by eight chloride ions thus forming sheets

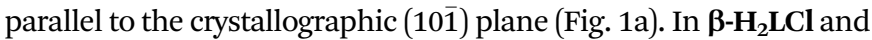
$\mathbf{H}_{2} \mathbf{L I}$ chains of $\left[\mathrm{H}_{2} \mathrm{~L}\right]^{+}$ions $[C(4)]$ are mutually connected via $\mathrm{Cl}^{-}$or $\mathrm{I}^{-}$ions (Fig. 1b and c). Each $\left[\mathrm{H}_{2} \mathrm{~L}\right]^{+}$ion is hydrogen bonded to four $\mathrm{Cl}^{-}$or $\mathrm{I}^{-}$ions in a 3D charge-assisted hydrogen bond framework (Fig. 1b, c and Table S4, ESI $\dagger$ ). Fingerprint plots and Hirshfeld surface analysis for $\mathbf{H}_{2} \mathbf{L C l}$ polymorphs are given in Fig. S3 (ESI $\dagger$ ). Most of the intermolecular contacts in $\boldsymbol{\alpha}-\mathbf{H}_{2} \mathbf{L C l}$ and $\boldsymbol{\beta}-\mathbf{H}_{2} \mathbf{L C l}$ are a)

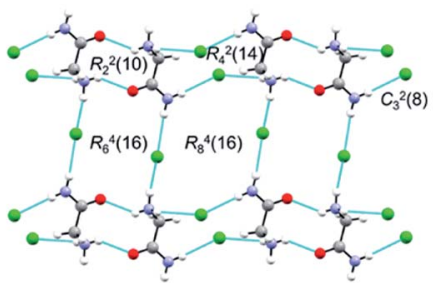

b)

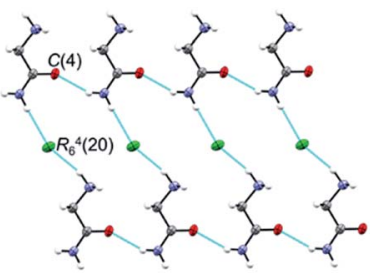

c)

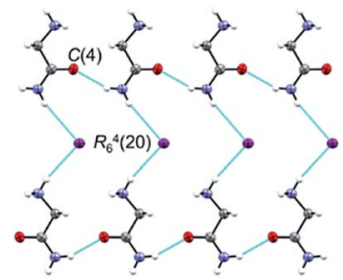

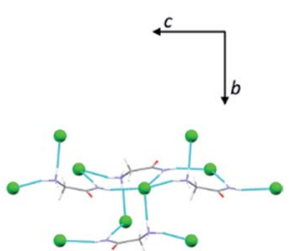
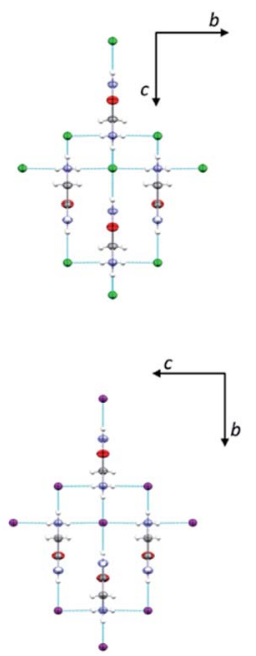

Fig. $1 \mathrm{HB}$-interactions in crystal structures of: (a) $\boldsymbol{\alpha}-\mathrm{H}_{2} \mathrm{LCl}$; (b) $\beta-\mathrm{H}_{2} \mathrm{LCl}$ and (c) $\mathrm{H}_{2} \mathrm{LI}$. In the $\alpha-\mathrm{H}_{2} \mathrm{LCl}$ polymorph, a layer of $\left[\mathrm{H}_{2} \mathrm{~L}\right]^{+}$and $\mathrm{Cl}^{-}$ions is parallel to the crystallographic (101) plane, while in $\beta-\mathrm{H}_{2} \mathrm{LCl}$ and $\mathrm{H}_{2} \mathrm{LI}$ an array of $\left[\mathrm{H}_{2} \mathrm{~L}\right]^{+}$ions is parallel to the crystallographic (010) and (001) plane, respectively (picture on the left). Hydrogen bonding of $\left[\mathrm{H}_{2} \mathrm{~L}\right]^{+}$ with four surrounding halides is presented on the right. Atoms are represented as small spheres of arbitrary radii $\left(\boldsymbol{\alpha}-\mathrm{H}_{2} \mathrm{LCl}\right.$ and all hydrogen atoms) or ellipsoids (at $50 \%$ probability level; $\boldsymbol{\beta}-\mathrm{H}_{2} \mathrm{LCl}$ and $\mathrm{H}_{2} \mathrm{LI}$ ). similar, however the most notable difference between the two structures is in the surrounding of the oxygen atom.

In $\boldsymbol{\beta}-\mathbf{H}_{2} \mathbf{L C l}$ the oxygen atom is in contact with $\mathrm{CH}_{2}$ and $\mathrm{NH}_{2}$ groups of the neighbouring $\mathrm{H}_{2} \mathrm{~L}^{+}$ion, while in $\boldsymbol{\alpha}-\mathbf{H}_{2} \mathbf{L C l}$ the oxygen atom is surrounded by two $-\mathrm{NH}_{3}{ }^{+}$groups, having more $\mathrm{H} \cdots \mathrm{H}$ contacts.

Molecular and crystal structures of $1 \mathrm{a}-\mathrm{c}, 2 \mathrm{a}, \mathrm{b}, 2 \mathrm{c}_{\mathrm{LT}}$ and $2 \mathrm{c}_{\mathrm{RT}}$

In cobalt(II) and nickel(II) compounds $\left[\mathrm{M}\left(\mathrm{H}_{2} \mathrm{O}\right)_{2}(\mathrm{HL})_{2}\right] \mathrm{X}_{2}(\mathrm{M}=$ Co, Ni; $\mathrm{X}=\mathrm{Cl}, \mathrm{Br} / \mathrm{Cl}, \mathrm{I}$ ), the metal(II) cation is octahedrally coordinated by two $\mathrm{N}, \mathrm{O}$-donating glycinamide ligands and two water molecules (Fig. S4, ESI $\dagger$ ). 1a, 1b, 2a and $\mathbf{2 b}$ are isostructural and crystallize in the tetragonal crystal system. 1c and $\mathbf{2 c}_{\mathbf{R T}}$ are also isostructural and crystallize in the orthorhombic crystal system (Tables S2 and S5, ESI $\dagger$ ). Two glycinamide molecules are bound to the metal ion via amido $\mathrm{O}$ and amino $\mathrm{N}$ atoms in a cis-fashion, and two water molecules occupy the axial coordination sites. Selected bond distances and angles in $\left[\mathrm{M}\left(\mathrm{H}_{2} \mathrm{O}\right)_{2}(\mathrm{HL})_{2}\right] \mathrm{X}_{2}(\mathrm{M}=\mathrm{Co}, \mathrm{Ni} ; \mathrm{X}=\mathrm{Cl}, \mathrm{Br} / \mathrm{Cl}, \mathrm{I})$ can be found in Tables $\mathrm{S} 6$ and $\mathrm{S} 7$ in ESI. $\dagger$

The same building block, a dimer, is found in the isostructural $\mathrm{Co}$ (II) and $\mathrm{Ni}$ (II) compounds $\mathbf{1 a}, \mathbf{1 b}, \mathbf{2 a}$ and $\mathbf{2 b}$ (Fig. 2a). A dimer consists of complex ion pairs mutually connected by four hydrogen bonds of the Ow-H $\cdots$ O type [graph-set

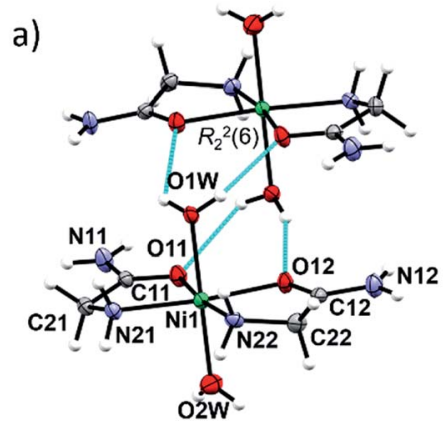

b)

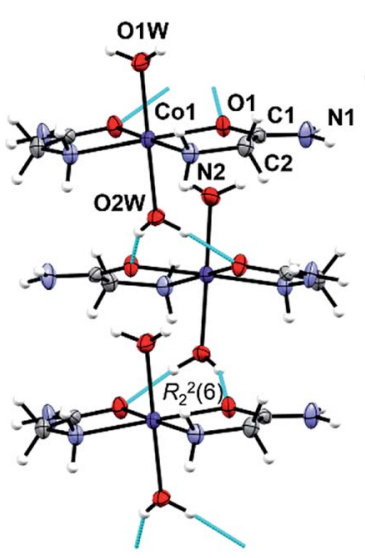

c)

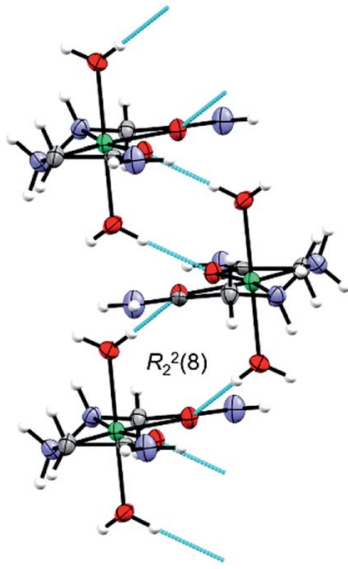

Fig. 2 (a) Discrete centrosymmetric dimers in $\left[\mathrm{Ni}(\mathrm{HL})_{2}\left(\mathrm{H}_{2} \mathrm{O}\right)_{2}\right]$ $\mathrm{Br}_{0.94} \mathrm{Cl}_{1.06}(2 \mathrm{~b})$ formed through intermolecular $\mathrm{OW}-\mathrm{H} \cdots \mathrm{O}$ hydrogen bonds (arrays of cyan cylinders). (b) Zig-zag chain of complex ions of $\left[\mathrm{Co}(\mathrm{HL})_{2}\left(\mathrm{H}_{2} \mathrm{O}\right)_{2}\right]^{2+}$ in $1 c$. (c) Zig-zag chain of complex ions of $\left[\mathrm{Ni}(\mathrm{HL})_{2}\left(\mathrm{H}_{2} \mathrm{O}\right)_{2}\right]^{2+}$ in $2 \mathrm{C}_{\mathrm{LT}}$. Atom labelling is analogous to $1 \mathrm{c}$, except for water molecules (O1W) which are symmetrically equivalent. 
$\left.R_{2}{ }^{2}(6)\right]$ (Fig. 2a, Tables S8 and S9, ESI $\dagger$ ). Halide ions ( $\mathrm{Cl}$ or $\mathrm{Br} / \mathrm{Cl}$ ) are placed between almost perpendicular dimers forming chains parallel to crystallographic $a$ axis (Fig. S5, ESI $\dagger$ ). The remaining hydrogen bond donors $\mathrm{N}-\mathrm{H}$ and $\mathrm{O}-\mathrm{H}$ are used for counter ion hydrogen bonding, thus forming a three dimensional framework.

In $\mathbf{1 c}, \mathbf{2} \mathbf{c}_{\mathbf{R T}}$ and $\mathbf{2 \mathbf { c } _ { \mathbf { L T } }}$ the complex ions are connected by $\mathrm{Ow}-\mathrm{H} \cdots$ $\mathrm{O}$ hydrogen bonds forming zig-zag chains along the $a$-axis (Fig. $2 \mathrm{~b}$ and $\mathbf{c}$, Tables S8 and S9, ESI $\dagger$ ). In $\mathbf{1 c}$ and $\mathbf{2 \mathbf { c } _ { \mathbf { R T } }}$ six-membered hydrogen bond rings are formed, $R_{2}{ }^{2}(6)$ (Fig. 2b), while in $2 \mathbf{c}_{\mathbf{L T}}$ the hydrogen bond rings are eight-membered, $R_{2}{ }^{2}(8)$ (Fig. 2c). Iodide ions are hydrogen bonded by $\mathrm{N}-\mathrm{H}$ and $\mathrm{O}-\mathrm{H}$ groups from three neighbouring cations thus forming a three dimensional framework (Fig. S6-S9, Tables S8 and S9, ESI ${ }^{\dagger}$ ).

Two polymorphs $\mathbf{2} \mathbf{c}_{\mathbf{R T}}$ and $\mathbf{2 \mathbf { c } _ { \mathbf { L T } }}$ are both cis-octahedral complexes with axial positions occupied by water molecules. At room temperature the orthorhombic polymorph $2 \mathbf{c}_{\mathbf{R T}}$ is the stable one, while at low temperature $(<220 \mathrm{~K})$ it transforms into the monoclinic polymorph $2 \mathbf{c}_{\mathbf{L T}}$. The main difference between the two is the orientation of water molecules (rotation by approx. $90^{\circ}$ ), which consequently changes the intermolecular interactions, as seen in Hirshfeld surface plots (Fig. S10, ESI $\dagger$ ). In $2 \mathbf{c}_{\mathbf{R T}}$ one water molecule $(\mathrm{O} 1 \mathrm{w})$ forms $\mathrm{Ow}-\mathrm{H} \cdots \mathrm{O}$ hydrogen bonds with two carbonyl oxygen atoms of adjacent complexes, while the other water molecule forms two $\mathrm{Ow}-\mathrm{H} \cdots \mathrm{I}$ hydrogen bonds. After rotation by $90^{\circ}$ at low temperature, both water molecules form both $\mathrm{Ow}-\mathrm{H} \cdots \mathrm{O}$ and $\mathrm{Ow}-\mathrm{H} \cdots \mathrm{I}$ hydrogen bonds (Table S9, ESI $\dagger$ ).

\section{Molecular and crystal structures of 3a-c}

The octahedral coordination environment around the $\mathrm{Cu}$ (II) ions in the structures of $\mathbf{3 a}$ and $\mathbf{3} \mathbf{b}$ consists of two $\mathrm{N}, \mathrm{O}$-bidentate glycinamide ligands and two halide ions ( $\mathrm{Cl}$ or $\mathrm{Br} / \mathrm{Cl}$ ) (Fig. 3 and $\mathrm{S} 11, \mathrm{ESI} \dagger)$. $\mathrm{Cu}(\mathrm{II})$ complex molecules are trans isomers. In the crystal structures of $\mathbf{3 a}$ and $\mathbf{3} \mathbf{b}$ all amide $\mathrm{H}$-atoms participate in hydrogen bonds with the neighboring halide ions (in total, every halide ion is hydrogen bonded by two amide $\mathrm{N}-\mathrm{H}$ and one amino $\mathrm{N}-\mathrm{H}$ hydrogen bond donor) forming a very dense three dimensional framework (Fig. S12, S13 and Table S11, ESI $\dagger$ ).

In terms of the crystal structure, the most interesting compound is 3c. It is a $1 \mathrm{D}$ coordination polymer built up of dinuclear copper $\left[\mathrm{Cu}_{2} \mathrm{I}_{6}\right]^{4-}$ and $\left[\mathrm{Cu}(\mathrm{HL})_{2}\right]^{2+}$ units (Fig. $4 \mathrm{a}$ ). The connectivity within this polymer is unique among the copper complexes since it is the only copper complex where the $\left[\mathrm{Cu}_{2} \mathrm{I}_{6}\right]^{4-}$ unit links four $\mathrm{Cu}(\mathrm{II})$ complex units, in this case $\left[\mathrm{Cu}(\mathrm{HL})_{2}\right]^{2+}$ (Fig. 4b). The two bridging atoms within the

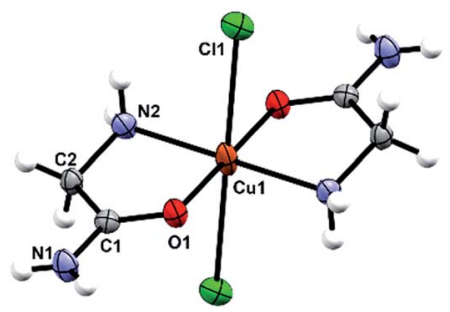

Fig. 3 Molecular structure of $3 a$ with the atom labelling scheme. Cu(॥) is located on the center of inversion (space group $P 2_{1} / n$ ). a)

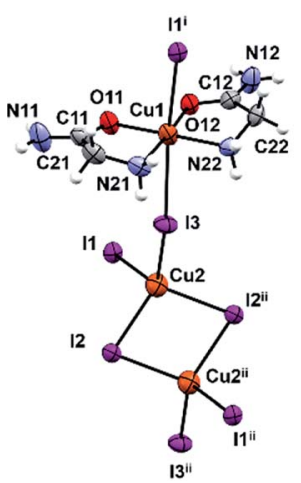

b)

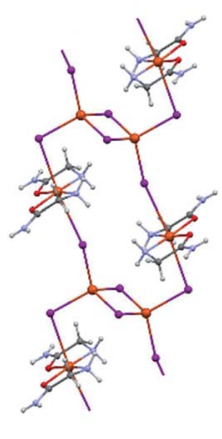

Fig. 4 (a) Molecular structure of 3c with atom labelling scheme. Cu(॥) are coordinated octahedrally in the cis- $\mathrm{HL}$ fashion. Two $\mathrm{Cu}(\mathrm{I})$ ions, $\mathrm{Cu} 2$ and $\mathrm{Cu} 2^{\mathrm{ii}}$ are both coordinated tetrahedrally with a shared edge. Symmetry operators $\mathrm{i}=-x, y-1,-z ; \mathrm{ii}=x+1, y-1, z-1$. (b) double chain of the coordination polymer.

$\left[\mathrm{Cu}_{2} \mathrm{I}_{6}\right]^{4-}$ unit are $\mathrm{I} 2$ and $\mathrm{I} 2^{\mathrm{ii}}$ (ii $=x+1, y-1, z-1$ ) with the corresponding Cu2-I bond lengths of 2.6696(12) and 2.7228(9) A. The $\left[\mathrm{Cu}_{2} \mathrm{I}_{6}\right]^{4-}$ unit $(\mathrm{Cu}(\mathrm{I})$ oxidation state) and the four $\left[\mathrm{Cu}(\mathrm{HL})_{2}\right]^{2+}$ units are connected through the I1 and I3 bridging atoms (and their centrosymmetrically related atoms). Cu(II)-I bonds are longer and amount to 3.1632(8) $\AA$ and 3.2963(8) $\AA$ (Table S12, ESI $\dagger$ ). These two copper centers have different coordination geometries having the main influence on the bond lengths. Those octahedrally coordinated generally have $\mathrm{Cu}-\mathrm{I}$ distances greater than $3 \AA$ although the radius of $\mathrm{Cu}(\mathrm{II})$ is smaller than of $\mathrm{Cu}(\mathrm{I})$. These results are in agreement with similar $\mathrm{Cu}^{\mathrm{I}} / \mathrm{Cu}^{\mathrm{II}}$ mixed oxidation state complexes. ${ }^{23,43-45}$ Coordination preferences of both $\mathrm{Cu}$ centres are also fulfilled: $\mathrm{Cu}(\mathrm{I})$ ions are tetrahedrally and $\mathrm{Cu}(\mathrm{II})$ ions octahedrally coordinated.

In the $\left[\mathrm{Cu}(\mathrm{HL})_{2}\right]^{2+}$ unit two glycinamide molecules bidentately chelate $\mathrm{Cu}(\mathrm{II})$ ions in a cis-fashion while iodide ions are found in axial positions. The inner chelate bond lengths indicate partial electron delocalization in the amide group, and the Jahn-Teller effect also influences elongation of the Cu1-I bonds. ${ }^{\mathbf{4 6}}$

Neighbouring $1 \mathrm{D}$ chains are connected by hydrogen bonds between amide $\mathrm{N}-\mathrm{H}$ bifurcated donors and $\mathrm{O}$ - and axial I-atom acceptors. These interactions are almost perpendicular to the chain propagation, Fig. S14 and S15 (ESI†). Inside one chain the glycinamide amino groups serve as $\mathrm{N}-\mathrm{H}$ donors to iodide ions that are coordinated to the $\mathrm{Cu}(\mathrm{I})$ ions (Table S13, ESI $\dagger$ ).

All compounds have two chelate rings in the equatorial plane, however the ring conformations are somewhat different. In isostructural $\mathbf{1 a}, \mathbf{1 b}, \mathbf{2 a}, \mathbf{2 b}$, as well as in $\mathbf{3 c}$ one 5 membered chelate ring adopts an envelope, and the other a half chair

Table 1 Conformations of chelate rings of the investigated compounds

\begin{tabular}{|c|c|}
\hline Compound & $\begin{array}{l}5 \text { membered chelate ring } \\
\text { conformations }\end{array}$ \\
\hline $1 \mathrm{a}, 1 \mathbf{1 b}, \mathbf{2 a}, 2 \mathbf{b}$ and $3 \mathrm{c}$ & Envelope and half chair \\
\hline $\mathbf{1 c}$ and $2 \mathbf{c}_{\mathrm{RT}}$ & Planar \\
\hline
\end{tabular}

5 membered chelate ring

Envelope and half chair Half chair 
conformation. In $\mathbf{1 c}$ and $\mathbf{2} \mathbf{c}_{\mathbf{R T}}$ both rings are planar, while in $\mathbf{3 a}$, $\mathbf{3 b}$ and $\mathbf{2} \mathbf{c}_{\mathbf{L T}}$ the chelate rings are in a half chair conformation (Table 1). A more detailed conformational analysis is given in Table S14 (ESI $\dagger$ ).

\section{Magnetic properties}

1a-b, 2a-c, 3a-c were investigated by X-band electron spin/ paramagnetic resonance (ESR/EPR) spectroscopy.

$\mathrm{Ni}(\mathrm{II})$ complexes $\left(\mathbf{2 a}, \mathbf{2 b}\right.$ and $\left.\mathbf{2} \mathbf{c}_{\mathbf{R T}}, \mathbf{2} \mathbf{c}_{\mathbf{L T}}(<220 \mathrm{~K})\right)$ were ESR silent i.e. from room down to $4 \mathrm{~K}$ no ESR signal was detected. This effect could be related to a high value of the zero-field splitting (ZFS) parameter of the Ni(II) ion or with the spinrelaxation phenomena. ${ }^{47}$ Additionally, it is also possible that, due to Jahn-Teller distortion, Ni(II) ions have a low-spin configuration $(S=0)$, instead of high-spin $(S=1)$ expected for octahedral complexes.

Representative spectra of 1a, 3a and 3c, obtained at several selected temperatures, are shown in Fig. 5 while the corresponding spectra of $\mathbf{1 b}$ and $\mathbf{3 b}$ are shown in Fig. S16, ESI. $\dagger$

The simulation of the spectra was performed by EasySpin software ${ }^{48}$ using the following form of the spin-Hamiltonian for $\mathrm{Cu}(\mathrm{II})$ and $\mathrm{Co}(\mathrm{II})$ ions: ${ }^{49}$

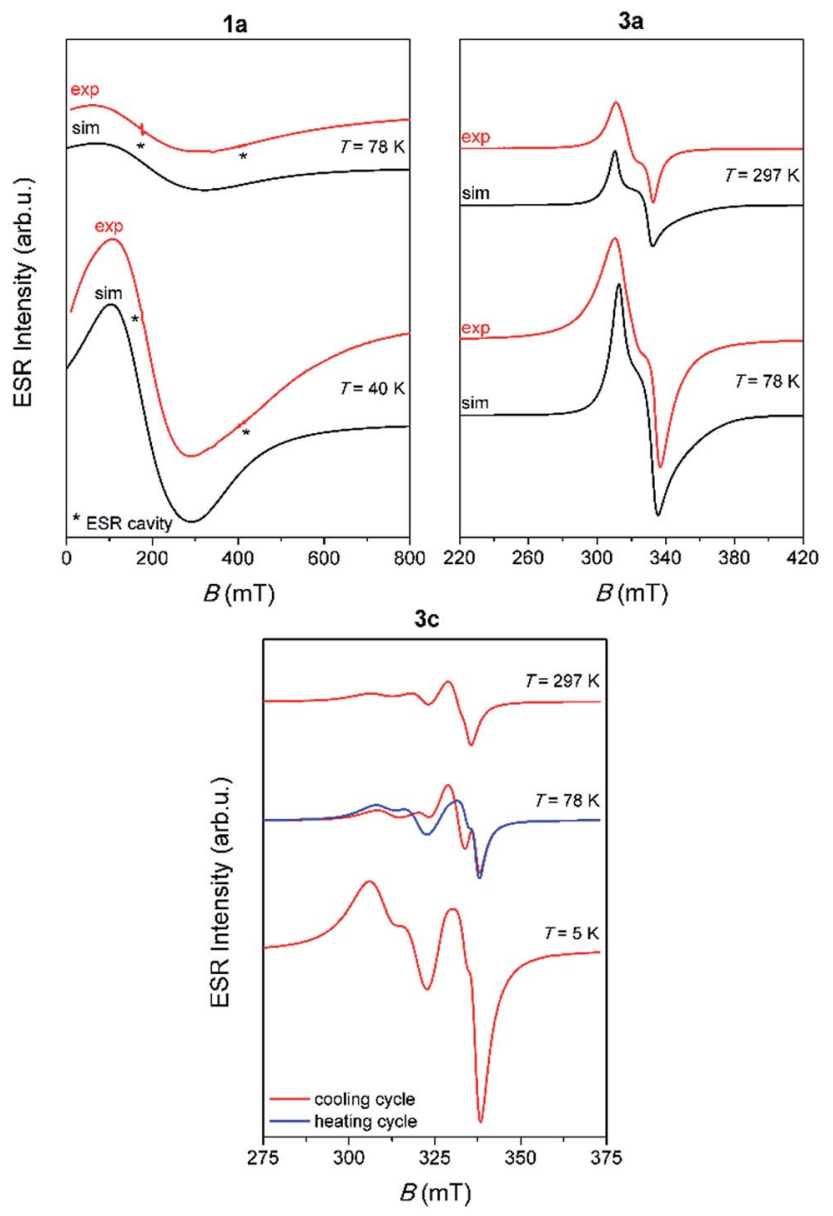

Fig. 5 Experimental (red lines) and simulated (black lines) ESR spectra of polycrystalline samples of the investigated complexes. The ESR intensities of the spectra at different temperatures are presented in the real ratios. The narrow lines labeled with asterisks originate from the ESR cavity.

$$
\mathbf{H}=\mu_{\mathrm{B}} \mathbf{B} \cdot \mathbf{g} \cdot \mathbf{S}
$$

In eqn (1), the constant $\mu_{\mathrm{B}}$ is the Bohr magneton, $\mathbf{g}$ is the $\mathbf{g}$ tensor, $\mathbf{B}$ is the magnetic field vector and $\mathbf{S}$ is the spin operator. Hyperfine interaction between electron spin $S=1 / 2$ and nuclear spin $I=3 / 2$ for $\mathrm{Cu}$ (II) ion was not detected probably due to weak interactions between $\mathrm{Cu}$ (II) ions (the nearest $\mathrm{Cu} \cdots \mathrm{Cu}$ distances are around $6.5 \AA$ ). For octahedral Co(II) ions in the high-spin state $S=3 / 2$, it is assumed that magnetic anisotropy is very large and therefore only the lowest states $(m=1 / 2$ and $m=-1$ / 2) are thermally occupied. ${ }^{50}$ As a result only one ESR line with very anisotropic $g$-values is observed. ${ }^{51}$ Also, hyperfine interaction for Co(II) ions were not detected. Therefore, the spectra for both $\mathrm{Cu}$ (II) and $\mathrm{Co}$ (II) ions were simulated using anisotropic $\mathbf{g}$ tensor and allowing only linewidth for assumed Lorentzian lineshape to change with temperature. The obtained $g$-values, together with the parameters used for the simulations, are given in Table S15 (ESI $\dagger$ ). For $\mathbf{3 a}$ and $\mathbf{3 b}$ complexes, it was necessary to include $\mathbf{g}_{\text {strain }}$ values in the simulation. Namely, small variations in the local geometry in $\mathrm{Cu}$ (II) octahedra can cause distribution of ESR parameters around some average $\boldsymbol{g}$-values, described by the $\mathbf{g}_{\text {strain }}$ parameter. ${ }^{52}$ This effect is not observed for $\mathbf{1 a}$ and $\mathbf{1 b}$ complexes because of their very broad ESR lines. The obtained $g$-values are the same for $\mathbf{3 a}$ and $\mathbf{3 b}$ complexes, as expected due to their similar crystal structures. Here obtained results for the $g$-values are in agreement with the $g$-values for $\mathrm{Cu}$ (II) and $\mathrm{Co}$ (II) ions that can be found in the literature. ${ }^{49-51,53}$

Contrary to the paramagnetic behaviour of $\mathbf{1 a}, \mathbf{1 b}, \mathbf{3 a}$ and $\mathbf{3 b}$ samples, 3c shows the most interesting magnetic behaviour, due to its linear $1 \mathrm{D}$ structure which contains dinuclear copper units $\left[\mathrm{Cu}_{2} \mathrm{I}_{6}\right]^{4-}(\mathrm{Cu} \cdots \mathrm{Cu}$ distance in the dimer is $3.2057 \AA)$. Beside the unusual ESR spectra, it was noticed that when the compound was heated from $5 \mathrm{~K}$ to $78 \mathrm{~K}$, the spectra show different patterns compared to the spectra recorded when the compound was cooled from $78 \mathrm{~K}$ to $5 \mathrm{~K}$, Fig. 5 . This observation points to possible interesting magnetic behaviour of this compound. Further investigation of $3 \mathbf{c}$ should also include magnetic susceptibility measurement.

\section{Biological assays}

Antiproliferative activities of 1a and 3a were tested on human lung (H 460), breast (MCF-7) and colon carcinoma (HCT116) cell lines (paragraph biological activity in the ESI $\dagger$ ). The tested compounds showed moderate antiproliferative activity towards the MCF-7 cell line, and minor to negligible activity towards HCT116 and H 460 cell lines. However, the effects of the two compounds were almost identical, pointing to negligible structural influence on their biological/antitumor activity (Table S16, ESI $\dagger$ ).

\section{Experimental}

\section{Materials and methods}

All chemicals for the syntheses were purchased from commercial sources (Aldrich, Acros or Alfa Aesar) and used as received without further purification. Glycinamide hydrochloride was 
prepared by aminolysis of chloroacetamide according to the method of E. Fischer. ${ }^{54} \mathrm{CHN}$ analyses were performed on a PerkinElmer 2400 Series II CHNS analyzer in the Analytical Services Laboratories of the Ruđer Bošković Institute, Zagreb, Croatia. The IR spectra were obtained in the range $4000-450 \mathrm{~cm}^{-1}$ on a PerkinElmer Spectrum Two ${ }^{\mathrm{TM}}$ FTIR-spectrometer in the ATR mode. TGA measurements were performed at a heating rate of $10{ }^{\circ} \mathrm{C} \min ^{-1}$ in the temperature range of $25-800{ }^{\circ} \mathrm{C}$, under an oxygen flow of $100 \mathrm{~mL} \mathrm{~min}^{-1}$ on a Mettler-Toledo TG/SDTA $851^{\mathrm{e}}$ instrument. Approximately 5-10 $\mathrm{mg}$ of each sample was placed in a standard alumina crucible $(70 \mu \mathrm{L})$. The NMR spectra of the ligand were recorded on a Bruker AV 600 spectrometer, operating at $600.130 \mathrm{MHz}$ for the ${ }^{1} \mathrm{H}$ nucleus and at $150.903 \mathrm{MHz}$ for the ${ }^{13} \mathrm{C}$ nucleus. The samples of the ligand were measured in DMSO$d_{6}$ solutions at $298 \mathrm{~K}$, using $5 \mathrm{~mm}$ NMR tubes. The chemical shifts in ppm were referenced to TMS.

The ESR measurements were performed on a Bruker Elexsys $580 \mathrm{FT} / \mathrm{CW}$ spectrometer from room down to liquid helium temperature. The microwave frequency was around $9.7 \mathrm{GHz}$ with the magnetic field modulation amplitude of $0.5 \mathrm{mT}$ and modulation frequency of $100 \mathrm{kHz}$. $\mathbf{3 a}$ and $\mathbf{3 b}$ complexes, due to observed passage effect ${ }^{55}$ at low temperatures, were recorded with modulation amplitude of $0.1 \mathrm{mT}$ and modulation frequency of $1 \mathrm{kHz}$.

\section{Synthetic procedures}

Preparation of glycinamide hydrochloride, $\mathrm{H}_{2} \mathrm{LCl}$ and $\mathrm{H}_{2} \mathrm{LI}$ $\boldsymbol{\beta}-\boldsymbol{H}_{2} \boldsymbol{L} \boldsymbol{C l}$. CAUTION - the experiment should be performed in a fume hood!

Chloroacetamide (18.6 g; $0.2 \mathrm{~mol}$ ) was mixed with a concentrated ammonia solution $(200 \mathrm{~mL})$ and the mixture was heated at $100{ }^{\circ} \mathrm{C}$ for $30 \mathrm{~min}$. The reaction mixture was then concentrated at $\approx 80{ }^{\circ} \mathrm{C} \neq$ until the product started to crystallize (the final volume was about $20-30 \mathrm{~mL}$ ) and immediately mixed with ethanol $(200 \mathrm{~mL})$. The reaction mixture was left to stand overnight in a refrigerator and the product was filtered off, washed with ethanol (50 mL) and air-dried. Additional amount of the product can be obtained by evaporation of the filtrate at room temperature. $\S$ When prepared in this manner, the product can be used without any further purification.

White crystals, yield: $16.8 \mathrm{~g}$ (76\%); mp $210{ }^{\circ} \mathrm{C} .{ }^{1} \mathrm{H}$ NMR (DMSO- $d_{6}, \delta$, ppm): $3.50(\mathrm{~s}, 2 \mathrm{H}) \mathrm{CH}_{2}, 7.49(\mathrm{~s}, \mathrm{br}, 1 \mathrm{H}) \mathrm{NH}^{\mathrm{a}}, 8.05$ (s, br, $1 \mathrm{H}) \mathrm{NH}^{\mathrm{b}}, 8.27(\mathrm{~s}, \mathrm{br}, 3 \mathrm{H}) \mathrm{NH}_{3}{ }^{+} .{ }^{13} \mathrm{C}$ NMR (DMSO- $d_{6}, \delta$, ppm): $39.85 \mathrm{CH}_{2}, 167.66 \mathrm{CONH}_{2}$. IR (ATR, cm ${ }^{-1}$ ): $3364(\mathrm{w})$, 3263(w), 3184(w), 2997(m), 2893(w), 2773(w), 2566(w), 1688(s), 1594(m), 1578(m), 1464(s), 1417(s), 1314(s), 1151(w), 1093(m), 1038(m), 891(s), 826(m), 528(w), 479(w).

$\boldsymbol{H}_{2} \mathbf{L I}$. Green crystals of $\mathbf{H}_{2} \mathbf{L I}$ were obtained from a solution containing $\mathrm{CoI}_{2}(0.156 \mathrm{~g}, 0.5 \mathrm{mmol}), \mathbf{H}_{2} \mathbf{L C l}(0.110 \mathrm{~g}, 1.0 \mathrm{mmol})$ and $\mathrm{NaHCO}_{3}(0.076 \mathrm{~g}, 0.9 \mathrm{mmol})$ and $10 \mathrm{~mL}$ of water in a very low yield. Crystals decomposed after several weeks.

\footnotetext{
\$ The reaction mixture becomes orange-coloured when overheated, leading to a very impure yellow-orange product which is not easily purified.

$\S$ Crystals obtained by slow evaporation of the filtrate were suitable for X-ray structural analysis.
}

\section{Preparation of complex compounds}

$\left[\mathrm{Co}\left(\mathrm{H}_{2} \mathrm{O}\right)_{2}(\mathrm{HL})_{2}\right] \mathrm{Cl}_{2}$ (1a). Cobalt(II) chloride hexahydrate $(0.24 \mathrm{~g}, 1.0 \mathrm{mmol})$, glycinamide hydrochloride $(0.22 \mathrm{~g}, 2.0$ $\mathrm{mmol})$ and sodium bicarbonate $(0.15 \mathrm{~g}, 1.8 \mathrm{mmol})$ were mixed in $10 \mathrm{~mL}$ of water. The mixture was stirred for few minutes, until the effervescence subsided, and was left to stand at room temperature. Rose-red crystals, suitable for X-ray structural analysis, were obtained. Anal. calc. for $\mathrm{C}_{4} \mathrm{H}_{16} \mathrm{~N}_{4} \mathrm{O}_{4} \mathrm{Cl}_{2} \mathrm{Co}$ : $\mathrm{C}$ 15.30, H 5.14, N 17.84\%. Found: C 15.42, H 4.66, N 17.83\%. IR $\left(\mathrm{ATR}, \mathrm{cm}^{-1}\right)$ : 3424(w), 3277(s), 3245(s), 3129(m), 2956(w), 2929(w), 2781(w), 1665(vs), 1595(s), 1461(m), 1422(m), 1343(w), 1313(w), 1196(w), 1134(vs), 1043(s), 944(w), 858(w), 767(w), 656(s), 601(s), 545(w), 488(w).

$\left[\mathrm{Co}\left(\mathrm{H}_{2} \mathrm{O}\right)_{2}(\mathrm{HL})_{2}\right] \mathrm{Br}_{1.06} \mathrm{Cl}_{0.94}(\mathbf{1 b})$. Cobalt(II) bromide $(0.22 \mathrm{~g}, 1.0$ $\mathrm{mmol})$, glycinamide hydrochloride $(0.22 \mathrm{~g}, 2.0 \mathrm{mmol})$ and sodium bicarbonate $(0.15 \mathrm{~g}, 1.8 \mathrm{mmol})$ were mixed in $10 \mathrm{~mL}$ of water. The mixture was stirred for few minutes, until the effervescence subsided, and was left to stand at room temperature. Rose-red crystals, suitable for $\mathrm{X}$-ray structural analysis, were obtained. Anal. calc. for $\mathrm{C}_{4} \mathrm{H}_{16} \mathrm{~N}_{4} \mathrm{O}_{4} \mathrm{Br}_{1.06} \mathrm{Cl}_{0.94} \mathrm{Co}$ : $\mathrm{C}$ 13.32, $\mathrm{H}$ 4.47, N 15.53\%. Found: C 13.31, H 3.98, N 15.34\%. IR $\left(\right.$ ATR, $\left.\mathrm{cm}^{-1}\right)$ : 3428(w), 3272(s), 3243(s), 3144(m), 2951(w), 2925(w), 2771(w), 1659(vs), 1586(s), 1455(m), 1417(m), 1340(w), 1312(w), 1193(w), 1129(s), 1040(s), 939(w), 856(w), 754(w), 635(s), 587(s), 542(w), 488(w).

$\left[\mathrm{Co}\left(\mathrm{H}_{2} \mathrm{O}\right)_{2}(\mathrm{HL})_{2}\right] \mathrm{I}_{2}(\mathbf{1 c})$. Cobalt(II) acetate dihydrate $(0.108 \mathrm{~g}$, $0.5 \mathrm{mmol})$, glycinamide hydrochloride $(0.111 \mathrm{~g}, 1.0 \mathrm{mmol})$ and potassium iodide $(0.166 \mathrm{~g}, 1.0 \mathrm{mmol})$ were mixed in $10 \mathrm{~mL}$ of water. Pink crystals, suitable for X-ray structural analysis, were obtained. Anal. calc. for $\mathrm{C}_{4} \mathrm{H}_{16} \mathrm{~N}_{4} \mathrm{O}_{4} \mathrm{I}_{2} \mathrm{Co}: \mathrm{C} 9.67, \mathrm{H} 3.25, \mathrm{~N}$ 11.27\%. Found: $\mathrm{C}$ 9.72, $\mathrm{H} 3.41, \mathrm{~N} 11.25 \%$. IR (ATR, $\mathrm{cm}^{-1}$ ): 3335(s), 3317(s), 3273(s), 3242(s), 3145(s), 2929(m), 2784(w), 1662(s), 1596(s), 1461(m), 1420(m), 1312(m), 1193(w), 1131(m), 1042(s), 940(w), 853(w), 766(w), 658(m), 596(m), 544(w), 493(w).

$\left[\mathrm{Ni}\left(\mathrm{H}_{2} \mathrm{O}\right)_{2}(\mathrm{HL})_{2}\right] \mathrm{Cl}_{2}$ (2a). Nickel(II) chloride hexahydrate $(0.24 \mathrm{~g}, 1.0 \mathrm{mmol})$, glycinamide hydrochloride $(0.22 \mathrm{~g}, 2.0$ $\mathrm{mmol})$ and sodium bicarbonate $(0.15 \mathrm{~g}, 1.8 \mathrm{mmol})$ were mixed in $10 \mathrm{~mL}$ of water. The mixture was stirred for few minutes, until the effervescence subsided, and was left to stand at room temperature. Light blue crystals, suitable for $\mathrm{X}$-ray structural analysis, were obtained. Anal. calc. for $\mathrm{C}_{4} \mathrm{H}_{16} \mathrm{~N}_{4} \mathrm{O}_{4} \mathrm{Cl}_{2} \mathrm{Ni}$ : C 15.31, H 5.14, N 17.86\%. Found: C 15.27, H 4.68, N 17.74\%. IR $\left(\mathrm{ATR}, \mathrm{cm}^{-1}\right)$ : 3432(w), 3285(s), 3250(s), 3114(m), 2958(w), 2933(w), 2786(w), 1677(vs), 1595(s), 1463(m), 1422(m), 1341(w), 1313(w), 1193(w), 1134(s), 1042(s), 946(w), 860(w), 768(w), 659(s), 605(s), 548(w), 495(w).

$\left[\mathrm{Ni}\left(\mathrm{H}_{2} \mathrm{O}\right)_{2}(\mathrm{HL})_{2}\right] \mathrm{Br}_{0.94} \mathrm{Cl}_{1.06}(\mathbf{2 b})$. Nickel(II) bromide (0.22 g, 1.0 $\mathrm{mmol})$, glycinamide hydrochloride $(0.22 \mathrm{~g}, 2.0 \mathrm{mmol})$ and sodium bicarbonate $(0.15 \mathrm{~g}, 1.8 \mathrm{mmol})$ were mixed in $10 \mathrm{~mL}$ of water. The mixture was stirred for few minutes, until the effervescence subsided, and was left to stand at room temperature. Light blue crystals, suitable for $\mathrm{X}$-ray structural analysis, were obtained. Anal. calc. for $\mathrm{C}_{4} \mathrm{H}_{16} \mathrm{~N}_{4} \mathrm{O}_{4} \mathrm{Br}_{0.94} \mathrm{Cl}_{1.06} \mathrm{Ni}$ : C 13.51, $\mathrm{H}$ 4.53, N 15.75\%. Found: $\mathrm{C}$ 13.66, $\mathrm{H}$ 4.06, $\mathrm{N} 15.81 \%$. IR $\left(\right.$ ATR, $\left.\mathrm{cm}^{-1}\right)$ : 3437(w), 3280(s), 3247(w), 3142(m), 2956(w), 2927(w), 2778(w), 1663(vs), 1592(s), 1458(m), 1418(m), 1338(w), 
1312(w), 1191(w), 1131(s), 1040(s), 941(w), 858(w), 755(w), 640(s), 592(s), 544(w), 495(w).

$\left[\mathrm{Ni}\left(\mathrm{H}_{2} \mathrm{O}\right)_{2}(\mathrm{HL})_{2}\right] \mathrm{I}_{2},\left(2 c_{\mathrm{RT}}\right)$. Nickel(II) iodide (0.31 g, $\left.1.0 \mathrm{mmol}\right)$, glycinamide hydrochloride $(0.22 \mathrm{~g}, 2.0 \mathrm{mmol})$, sodium bicarbonate $(0.15 \mathrm{~g}, 1.8 \mathrm{mmol})$ were mixed in $10 \mathrm{~mL}$ of water. Blue crystals, suitable for X-ray structural analysis, were obtained. Anal. calc. for $\mathrm{C}_{4} \mathrm{H}_{16} \mathrm{~N}_{4} \mathrm{O}_{4} \mathrm{I}_{2} \mathrm{Ni}$ : C 9.67, H 3.25, N 11.28\%. Found: C 9.35, H 3.64, N 11.40\%. IR (ATR, $\mathrm{cm}^{-1}$ ): 3343(s), 3322(s), 3275(s), 3179(s), 2939(m), 2758(w), 1646(s), 1596(s), 1575(s), 1461(m), 1411(m), 1318(m), 1297(m), 1193(w), 1120(m), 1036(s), 935(w), 846(w), 766(w), 682(m), 594(s), 556(m), 505(m).

$\left[\mathrm{CuCl}_{2}(\mathrm{HL})_{2}\right]$ (3a). Copper(II) chloride dihydrate $(0.17 \mathrm{~g}, 1.0$ $\mathrm{mmol})$, glycinamide hydrochloride $(0.22 \mathrm{~g}, 2.0 \mathrm{mmol})$ and sodium bicarbonate $(0.15 \mathrm{~g}, 1.8 \mathrm{mmol})$ were mixed in $10 \mathrm{~mL}$ of water. The mixture was stirred for few minutes, until the effervescence subsided, and was left to stand at room temperature. Dark blue crystals, suitable for X-ray structural analysis, were obtained. Anal. calc. for $\mathrm{C}_{4} \mathrm{H}_{16} \mathrm{~N}_{4} \mathrm{O}_{2} \mathrm{Cl}_{2} \mathrm{Cu}$ : C 17.00, H 4.28, N 19.82\%. Found: C 17.18, H 3.81, N 19.82\%. IR (ATR, $\mathrm{cm}^{-1}$ ): 3290(m), 3217(w), 3144(m), 2987(w), 2953(w), 2757(w), 1674(m), 1632(vs), 1579(vs), 1462(m), 1416(m), 1343(m), 1290(w), 1180(w), 1122(vs), 1101(vs), 1056(m), 948(m), 857(w), 777(m), 692(s), 651(s), 563(m), 509(m), 460(m).

$\left[\mathrm{CuBr}_{1.3} \mathrm{Cl}_{0.7}(\mathrm{HL})_{2}\right]$ (3b). Copper(II) bromide $(0.22 \mathrm{~g}, 1.0$ $\mathrm{mmol})$, glycinamide hydrochloride $(0.22 \mathrm{~g}, 2.0 \mathrm{mmol})$ and sodium bicarbonate $(0.15 \mathrm{~g}, 1.8 \mathrm{mmol})$ were mixed in $10 \mathrm{~mL}$ of water. The mixture was stirred for few minutes, until the effervescence subsided, and was left to stand at room temperature. Dark blue crystals, suitable for $\mathrm{X}$-ray structural analysis, were obtained. Anal. calc. for $\mathrm{C}_{4} \mathrm{H}_{16} \mathrm{~N}_{4} \mathrm{O}_{2} \mathrm{Br}_{1.3} \mathrm{Cl}_{0.7} \mathrm{Cu}$ : C 14.11, $\mathrm{H}$ 3.55, N 16.46\%. Found: C 13.97, H 4.18, N 16.18\%. IR $\left(\right.$ ATR, $\left.\mathrm{cm}^{-1}\right)$ : 3282(m), 3209(w), 3137(m), 2981(w), 2949(w), 2746(w), 1669(m), 1633(vs), 1572(vs), 1456(m), 1415(m), 1339(m), 1290(w), 1177(w), 1118(vs), 1100(vs), 1055(m), 946(m), 852(w), 755(m), 677(s), 646(s), 560(m), 506(m), 460(m).

$\left\{\left[\mathrm{Cu}^{\mathrm{II}}(\mathrm{HL})_{2}\right]_{2}\left[\mathrm{Cu}_{2}{ }_{2} I_{6}\right]\right\}_{n} \quad$ (3c). Copper(II) chloride dihydrate $(0.17 \mathrm{~g}, 1 \mathrm{mmol})$, glycinamide hydrochloride $(0.22 \mathrm{~g}, 2.0 \mathrm{mmol})$ and sodium bicarbonate $(0.15 \mathrm{~g}, 1.8 \mathrm{mmol})$ were mixed in $10 \mathrm{~mL}$ of water. After the effervescence subsided, solid potassium iodide ( $0.35 \mathrm{~g}, 2 \mathrm{mmol}$ ) was added into the solution. The colour changed from dark blue to olive-green, leading to brown crystals, suitable for $\mathrm{X}$-ray structural analysis. Anal. calc. for $\mathrm{C}_{4}$ $\mathrm{H}_{12} \mathrm{~N}_{4} \mathrm{O}_{2} \mathrm{I}_{3} \mathrm{Cu}_{2}$ : C 7.32, H 1.84, N 8.54\%. Found: C 7.44, H 2.12, N 8.36\%. IR (ATR, $\mathrm{cm}^{-1}$ ): 3380(m), 3310(vs), 3267(vs), 3201(s), 3119(s), 2953(w), 2912(w), 1672(m), 1644(vs), 1555(vs), 1457(m), 1401(m), 1321(w), 1293(w), 1174(w), 1108(s), 1054(m), 1034(m), 929(w), 852(w), 687(w), 620(m), 583(m), 548(m), 480(m).

\section{Crystallization of complex compounds}

All compounds crystallized from aqueous solutions by slow evaporation of solvent at room temperature. 1a, 1b, 2a, 2b, 3a, and $\mathbf{3 b}$ crystalized after several days. Coordination polymer $\mathbf{3 c}$ crystallized within minutes upon addition of potassium iodide due to very low solubility. On the other hand, $\mathbf{1 c}$ and $\mathbf{2 \mathbf { c } _ { \mathbf { R T } }}$ are highly soluble in water, hence crystallization occurred after several months.

\section{X-ray crystallography}

The single-crystal X-ray diffraction data of $\boldsymbol{\beta}-\mathbf{H}_{2} \mathbf{L C l}, \mathbf{H}_{2} \mathbf{L I}, \mathbf{1 a}-\mathbf{c}$, $\mathbf{2 a}, \mathbf{2 b}, \mathbf{2 c _ { \mathbf { L T } }}, \mathbf{2 \mathbf { c } _ { \mathbf { R T } }}$, 3a-c were collected by $\omega$-scans on an Oxford Diffraction Xcalibur3 CCD diffractometer with graphitemonochromated $\mathrm{MoK}_{\alpha}$ radiation. Data reduction was performed using the CrysAlis software package. ${ }^{56}$ Solution, refinement and analysis of the structures were done using the programs integrated in the WinGX system. ${ }^{57}$ All structures were solved by the direct methods using SHELXS and the refinement procedure was performed by the full-matrix least-squares method based on $F^{2}$ against all reflections using SHELXL. ${ }^{58,59}$ The non-hydrogen atoms were refined anisotropically. All hydrogen atoms were located in the difference Fourier maps. Because of poor geometry for some of them they were placed in calculated positions and refined using the riding model. In structures $\mathbf{1 b}, \mathbf{2 b}$ and $\mathbf{3 b}$ bromide and chloride ions statistically occupy almost the same site (slightly longer distances are associated with the bromide ion). Displacement parameters of these ions were restrained to the same values. Occupancies were refined to the final ratios $\mathrm{Br} / \mathrm{Cl}: 1.06: 0.94$ in $1 \mathrm{~b}, 0.94: 1.06$ in $2 \mathbf{b}$, and $1.3: 0.7$ in $3 \mathbf{b}$. Geometrical calculations were done using PLATON. ${ }^{60}$ Drawings of the structures were prepared using PLATON and MERCURY program. ${ }^{61}$ The crystallographic data are summarized in Tables $\mathrm{S} 2$ and S5, see ESI. $\dagger$

Crystal data for $\beta-\mathrm{H}_{2} \mathbf{L C l} . \mathrm{C}_{2} \mathrm{H}_{7} \mathrm{~N}_{2} \mathrm{OCl}, M=110.55$, monoclinic, $a=4.6688(9), b=6.2057(13), c=8.898(2) \AA, \beta=$ $101.486(19)^{\circ}, V=252.65(10) \AA^{3}, T=293 \mathrm{~K}$, space group $P 2_{1} / m$ (no. 11), $Z=2,1268$ reflections measured, 543 unique $\left(R_{\text {int }}=\right.$ $0.024)$. Final $R(F, I>2 \sigma(I))$ value was $0.0369, w R_{2}\left(F^{2}, I>2 \sigma(I)\right)=$ $0.0977, S=1.09$. CCDC 1915366. $\dagger$

Crystal data for $\mathrm{H}_{2}$ LI. $\mathrm{C}_{2} \mathrm{H}_{7} \mathrm{~N}_{2} \mathrm{OI}, M=202.00$, orthorhombic, $a=4.6880(1), b=18.6082(4), c=6.7363(2) \AA, V=587.64(2) \AA^{3}, T$ $=295 \mathrm{~K}$, space group $P b c m$ (no. 57), $Z=4,4855$ reflections measured, 929 unique $\left(R_{\mathrm{int}}=0.023\right)$. Final $R(F, I>2 \sigma(I))$ value was $0.0188, w R_{2}\left(F^{2}, I>2 \sigma(I)\right)=0.0430, S=1.11$. CCDC 1915367. $\dagger$

Crystal data for 1a. $\mathrm{C}_{4} \mathrm{H}_{16} \mathrm{~N}_{4} \mathrm{O}_{4} \mathrm{CoCl}_{2}, M=314.04$, tetragonal, $a=11.3145(2), b=11.3145(2), c=37.9735(8) \AA, V=4861.3(2)$ $\AA^{3}, T=293 \mathrm{~K}$, space group $I 4_{1} c d$ (no. 110), $Z=16,26763$ reflections measured, 2660 unique $\left(R_{\mathrm{int}}=0.024\right)$. Final $R(F, I>$ $2 \sigma(I))$ value was $0.0169, w R_{2}\left(F^{2}, I>2 \sigma(I)\right)=0.0426, S=1.13$. CCDC 1915368. $\dagger$

Crystal data for 1 b. $\mathrm{C}_{4} \mathrm{H}_{16} \mathrm{~N}_{4} \mathrm{O}_{4} \mathrm{CoBr}_{1.06} \mathrm{Cl}_{0.94}, M=360.88$, tetragonal, $a=11.3708(2), b=11.3708(2), c=38.3225(14) \AA, V=$ 4954.9(3) $\AA^{3}, T=150 \mathrm{~K}$, space group $I 4_{1} c d$ (no. 110 ), $Z=16$, 15188 reflections measured, 2501 unique $\left(R_{\text {int }}=0.036\right)$. Final $R(F, I>2 \sigma(I))$ value was $0.0238, w R_{2}\left(F^{2}, I>2 \sigma(I)\right)=0.0538, S=$ 1.03. CCDC 1915361.†

Crystal data for 1c. $\mathrm{C}_{4} \mathrm{H}_{16} \mathrm{~N}_{4} \mathrm{O}_{4} \mathrm{CoI}_{2}, M=496.94$, orthorhombic, $a=7.3966(4), b=19.1784(8), c=10.1512(4) \AA, V=$ 1440.00(11) $\AA^{3}, T=150 \mathrm{~K}$, space group Pnma (no. 62), $Z=4$, 4648 reflections measured, 1606 unique $\left(R_{\mathrm{int}}=0.042\right)$. Final $R(F$, $I>2 \sigma(I))$ value was $0.0327, w R_{2}\left(F^{2}, I>2 \sigma(I)\right)=0.0602, S=1.03$. CCDC 1915362. $\dagger$

Crystal data for $2 \mathrm{a} . \mathrm{C}_{4} \mathrm{H}_{16} \mathrm{~N}_{4} \mathrm{O}_{4} \mathrm{NiCl}_{2}, M=313.82$, tetragonal, $a=11.2394(5), b=11.2394(5), c=37.594(4) \AA, V=4749.0(7) \AA^{3}, T$ $=150 \mathrm{~K}$, space group $I 4_{1} c d$ (no. 110), $Z=16,21338$ reflections 
measured, 4042 unique $\left(R_{\text {int }}=0.030\right)$. Final $R(F, I>2 \sigma(I))$ value was 0.0269, $w R_{2}\left(F^{2}, I>2 \sigma(I)\right)=0.0592, S=1.08$. CCDC 1915364. $\dagger$

Crystal data for 2 b. $\mathrm{C}_{4} \mathrm{H}_{16} \mathrm{~N}_{4} \mathrm{O}_{4} \mathrm{NiBr}_{0.94} \mathrm{Cl}_{1.06}, M=355.61$, tetragonal, $a=11.3175(3), b=11.3175(3), c=38.0842(14) \AA$. $V=$ 4878.1(3) $\AA^{3}, T=150 \mathrm{~K}$, space group $I 4_{1} c d$ (no. 110), $Z=16$, 11070 reflections measured, 2662 unique $\left(R_{\mathrm{int}}=0.028\right)$. Final $R(F, I>2 \sigma(I))$ value was $0.0223, w R_{2}\left(F^{2}, I>2 \sigma(I)\right)=0.0485, S=$ 1.10. CCDC 1915369. $\dagger$

Crystal data for $2 \mathrm{c}_{\mathrm{RT}} \cdot \mathrm{C}_{4} \mathrm{H}_{16} \mathrm{~N}_{4} \mathrm{O}_{4} \mathrm{NiI}_{2}, M=496.72$, orthorhombic, $a=7.5456(3), b=18.9706(7), c=10.1902(3) \AA, V=$ 1458.67(9) $\AA^{3}, T=295 \mathrm{~K}$, space group Pnma (no. 62), $Z=4,5770$ reflections measured, 1626 unique $\left(R_{\text {int }}=0.024\right)$. Final $R(F, I>$ $2 \sigma(I))$ value was $0.0299, w R_{2}\left(F^{2}, I>2 \sigma(I)\right)=0.0698, S=1.09$. CCDC 1915363. $\dagger$

Crystal data for $2 \mathbf{c}_{\mathbf{L T}} \cdot \mathrm{C}_{4} \mathrm{H}_{16} \mathrm{~N}_{4} \mathrm{O}_{4} \mathrm{NiI}_{2}, M=496.72$, monoclinic, $a=7.2589(7), b=10.3706(10), c=19.2258(17) \AA, \beta=$ 98.742(9) $)^{\circ}, V=1430.5(2) \AA^{3}, T=150 \mathrm{~K}$, space group $I 2 / a$ (no. 15), $Z=4$, 2506 reflections measured, 2506 unique $\left(R_{\text {int }}=0.038\right)$. Final $R(F, I>2 \sigma(I))$ value was $0.0353, w R_{2}\left(F^{2}, I>2 \sigma(I)\right)=0.1020, S$ $=1.19$. CCDC 1915370. $\dagger$

Crystal data for 3a. $\mathrm{C}_{4} \mathrm{H}_{12} \mathrm{~N}_{4} \mathrm{O}_{2} \mathrm{CuCl}_{2}, M=282.62$, monoclinic, $a=6.8813(2), b=7.7420(2), c=9.2635(2) \AA, \beta=$ $101.779(3)^{\circ}, V=483.12(2) \AA^{3}, T=293 \mathrm{~K}$, space group $P 2_{1} / n$ (no. 14), $Z=2,11873$ reflections measured, 1159 unique $\left(R_{\text {int }}=\right.$ $0.016)$. Final $R(F, I>2 \sigma(I))$ value was $0.0151, w R_{2}\left(F^{2}, I>2 \sigma(I)\right)=$ $0.0479, S=0.98$. CCDC 1915371. $\dagger$

Crystal data for 1b. $\mathrm{C}_{4} \mathrm{H}_{12} \mathrm{~N}_{4} \mathrm{O}_{2} \mathrm{CuBr}_{1.3} \mathrm{Cl}_{0.7}, M=340.41$, monoclinic, $a=7.0098(5), b=7.8128(3), c=9.4100(5) \AA$, $\beta=$ $101.963(6)^{\circ}, V=504.16(5) \AA^{3}, T=293 \mathrm{~K}$, space group $P 2_{1} / n$ (no. 14), $Z=2,4025$ reflections measured, 1092 unique $\left(R_{\text {int }}=\right.$ $0.028)$. Final $R(F, I>2 \sigma(I))$ value was $0.0238, w R_{2}\left(F^{2}, I>2 \sigma(I)\right)=$ $0.0571, S=1.12$. CCDC 1915372. $\dagger$

Crystal data for $3 c . \mathrm{C}_{4} \mathrm{H}_{12} \mathrm{~N}_{4} \mathrm{O}_{2} \mathrm{Cu}_{2} \mathrm{I}_{3}, M=655.96$, triclinic, $a=8.0185(4), b=8.6901(4), c=11.0929(5) \AA, \alpha=84.575(4), \beta=$ $77.367(4), \gamma=72.679(4)^{\circ}, V=719.69(6) \AA^{3}, T=293 \mathrm{~K}$, space group $P \overline{1}$ (no. 2), $Z=2$, 7861 reflections measured, 3084 unique $\left(R_{\text {int }}=0.039\right)$. Final $R(F, I>2 \sigma(I))$ value was $0.0259, w R_{2}\left(F^{2}, I>\right.$ $2 \sigma(I))=0.0686, S=0.84$. CCDC 1915365. $\dagger$

\section{Conclusions}

New cobalt(II), nickel(II) and copper(II) compounds with glycinamide were prepared and characterized by X-ray crystallography, IR spectroscopy and thermal analysis.

Cobalt(II) and nickel(II) compounds 1a-1c and 2a-2c have an analogous chemical composition, $\left[\mathrm{M}(\mathrm{HL})_{2}\left(\mathrm{H}_{2} \mathrm{O}\right)_{2}\right] \mathrm{X}_{2}$. In these compounds two glycinamide ligands coordinate $\mathrm{Co}$ (II) or $\mathrm{Ni}$ (II) ions in the $\mathrm{N}, \mathrm{O}$-bidentate chelating mode arranged in a cisconfiguration, while water molecules occupy the axial coordination sites. Halide ions are counter-ions in all six mentioned complexes. Copper compounds $\mathbf{3 a}$ and $\mathbf{3} \mathbf{b}$ are trans isomers with two $\mathrm{N}, \mathrm{O}$-bidentate glycinamide ligands in the equatorial plane and two halide ions coordinated at the axial coordination sites.

Interestingly, bromide and chloride ions are almost equally preferred by cobalt(II) and nickel(II) complex ions, hence crystal structures are disordered at the halide ion position. Bromide and chloride ions occupy the same positions in the $\mathrm{Br} / \mathrm{Cl}$ ratio close to
$1: 1$ (1.06: 0.94 in $\mathrm{Co}$ (II) complexes; $0.94: 1.06$ in $\mathrm{Ni}$ (II) compounds). Copper(II) ion, on the other hand, has slightly more preference towards the bromide ion, which resulted in $\mathrm{Br}$ to $\mathrm{Cl}$ ratio $1.3: 0.7$. Copper showed interesting chemical behavior in reaction of copper(II) ions, glycinamide and iodide ions. Copper(II) was partially reduced to copper(I) and the coordination polymer $3 \mathbf{c}$ was formed with mixed oxidation states of copper. 1D polymer 3c contains double chains of copper(II) coordinated by two glycinamide ligands in a cis configuration bridged by $\left[\mathrm{Cu}_{2} \mathrm{I}_{6}\right]^{4-}$ species. 3c also showed possible interesting magnetic properties which will be investigated in more details in further research. 1a and $\mathbf{3 a}$ were tested for antiproliferative activity. Both compounds showed no activity towards HCT116 and H 460 cell lines, but moderate activity $\left(\mathrm{GI}_{50}\right.$ just above $10 \mu \mathrm{mol} \mathrm{dm}{ }^{-3}$ ) and selectivity was found towards the MCF-7 cell line.

CCDC 1915361-1915372 contain the supplementary crystallographic data for this paper. $\dagger$

\section{Conflicts of interest}

There are no conflicts of interest to declare.

\section{Acknowledgements}

Financial support by the Croatian Science Foundation (grant no. IP-2014-09-4274 and IP-2018-01-3168) is gratefully acknowledged. The authors are grateful to Dr Marijeta Kralj and Dr Lidija Uzelac for testing compounds for antiproliferative activity.

\section{Notes and references}

1 C. Kutzscher, P. Müller, S. Raschke and S. Kaskel, in The Chemistry of Metal-Organic Frameworks: Synthesis, Characterization, and Applications, ed. S. Kaskel, Wiley-VCH Verlag GmbH \& Co. KGaA, Weinheim, 1st edn, 2016, Chiral Linker Systems, pp. 387-418.

2 I. Dokmanić, M. Šikić and S. Tomić, Acta Crystallogr., Sect. D: Biol. Crystallogr., 2008, 64(3), 257-263.

3 P. J. Almhjell and J. H. Mills, Curr. Opin. Struct. Biol., 2018, 51, 170-176.

4 K. Užarević, I. Halasz, I. Đilović, N. Bregović, M. Rubčić, D. Matković-Čalogović and V. Tomišić, Angew. Chem., Int. Ed., 2013, 52, 5504-5508.

5 U. G. K. Wegst, H. Bai, E. Saiz, A. P. Tomsia and R. O. Ritchie, Nat. Mater., 2014, 14, 23-26.

6 J. Aizenberg and P. Fratzl, Adv. Mater., 2009, 21, 387-388.

7 J. Aizenberg, Adv. Mater., 2004, 16, 1295-1302.

8 E. L. Hegg and J. N. Burstyn, Coord. Chem. Rev., 1998, 173, 133-165.

9 K. L. Haas and K. J. Franz, Chem. Rev., 2009, 109(10), 49214960.

10 D. L. Stone, D. K. Smith and A. C. Whitwood, Polyhedron, 2004, 23, 1709-1717.

11 M. M. Harding, Acta Crystallogr., Sect. D: Biol. Crystallogr., 1999, 55, 1432-1443.

12 M. M. Harding, Acta Crystallogr., Sect. D: Biol. Crystallogr., 2000, 56, 857-867. 
13 M. M. Harding, Acta Crystallogr., Sect. D: Biol. Crystallogr., 2001, 57, 401-411.

14 M. M. Harding, Acta Crystallogr., Sect. D: Biol. Crystallogr., 2004, 60, 849-859.

15 M. M. Harding, Acta Crystallogr., Sect. D: Biol. Crystallogr., 2006, 62, 678-682.

16 E. Andersson, P. Horal, A. Jejcic, S. Höglud, J. Balzarini, A. Vahle and B. Svennerholm, Antimicrob. Agents Chemother., 2005, 49(1), 40-44.

17 Z. H. Chohan, M. Arif, M. A. Akhtar and C. T. Supuran, Bioinorg. Chem. Appl., 2006, 1-13.

18 D. Kannan and M. N. Arumugham, Int. J. Res. Controlled Release, 2012, 2(4), 10-17.

19 X. Li, Z. Zhang, C. Wang, T. Zhang, K. He and F. Deng, J. Inorg. Biochem., 2011, 105, 23-30.

20 X. Liu, X. Li, Z. Zhang, Y. Dong, P. Liu and C. Zhang, Biol. Trace Elem. Res., 2013, 154, 150-155.

21 D. Vušak, B. Prugovečki, D. Milić, M. Marković, I. Petković, M. Kralj and D. Matković-Čalogović, Cryst. Growth Des., 2017, 17, 6049-6061.

22 S. M.-F. Lo, S. S.-Y. Chui, L.-Y. Shek, Z. Lin, X. X. Zhang, G. Wen and I. D. Williams, J. Am. Chem. Soc., 2000, 122, 6293-6294.

23 D. A. Firmin, E. R. Quilano, R. Cameron, A. K. Pant, E. D. Stevens and C. J. O'Connor, Inorg. Chim. Acta, 1990, 172, 211-220.

24 A. V. Pestov, P. A. Slepukhin and V. N. Charushin, Russ. Chem. Rev., 2015, 84, 210-333.

25 T.-F. Liu and Z.-X. Wang, Inorg. Chem. Commun., 2013, 30, 84-87.

26 W. Wen, X. Jimin and X. Yawen, J. Coord. Chem., 2009, 62, 373-379.

27 T. Adam, Klin. Biochem. Metab., 2005, 13(34), 177-181.

28 C. R. Groom, I. J. Bruno, M. P. Lightfoot and S. C. Ward, Acta Crystallogr., Sect. B: Struct. Sci., Cryst. Eng. Mater., 2016, 72, 171-179.

29 B. Ganguly, M. K. Kesharwani, N. Basarić, E. Suresh, A. K. Biswas and K. Mlinarić-Majerski, J. Mol. Graphics Modell., 2013, 46, 52-58.

30 A. Fehn, S. Mihan, K. Polborn and W. Beck, Z. Anorg. Allg. Chem., 1997, 623, 665-675.

31 R. Krämer, M. Maurus, R. Bergs, K. Polborn, K. Sünkel, B. Wagner and W. Beck, Chem. Ber., 1993, 126, 1969-1980.

32 N. Usuki, M. Yamada, M. Ohba and H. Ōkawa, J. Solid State Chem., 2001, 159, 328-335.

33 Y. Ilan and M. Kapon, Inorg. Chem., 1986, 25, 2350-2354.

34 M. Graf, K. Karaghiosoff, P. Mayer and W. Beck, Z. Anorg. Allg. Chem., 2013, 639(7), 1117-1121.

35 W. Kaim, B. Schwederski and A. Klein, Bioinorganic chemistry-Inorganic elements in the chemistry of life, John Wiley \& Sons, Chichester, 2nd edn, 2013.

36 J. Pejić, D. Vušak, G. Szalontai, B. Prugovečki, D. MrvošSermek, D. Matković-Čalogović and J. Sabolović, Cryst. Growth Des., 2018, 18(9), 5138-5154.

37 M. Tašner, B. Prugovečki, Ž. Soldin, S. Prugovečki, L. Rukavina and D. Matković-Čalogović, Polyhedron, 2013, 52, 268-275.
38 M. Tašner, B. Prugovečki, D. Mrvoš-Sermek, B. Korpar-Čolig, G. Giester and D. Matković-Čalogović, Acta Chim. Slov., 2008, 55(4), 928-934.

39 M. Tašner, D. Mrvoš-Sermek, E. Hajdarpašić and D. Matković-Čalogović, Sec. Nat. Math. Biotech. Sci., MASA, 2018, 39(2), 91-101.

40 N. Smrečki, O. Jović, B.-M. Kukovec, E. Šimunić, S. Vuk, A. Skuhala, M. Babić, T. Rončević, N. Ilić, I. Kekez, D. Matković-Čalogović and Z. Popović, Inorg. Chim. Acta, 2018, 471, 521-529.

41 R. M. Silverstein, F. X. Webster and D. J. Kiemle, Spectrometric Identification of Organic Compounds, John Wiley \& Sons, Inc., Hoboken, 7th edn, 2005.

42 K. Nakamoto, Infrared and Raman Spectra of Inorganic and Coordination Compounds, Part B, John Wiley \& Sons, Inc., Hoboken, 6th edn, 2009.

43 S. Myllyviita and R. Sillanpää, J. Chem. Soc., Dalton Trans., 1994, 2125-2128.

44 B. Freckmann and K.-F. Tebbe, Z. Naturforsch., B: J. Chem. Sci., 1980, 35, 1319-1321.

45 S. Zhang, Y. Cao, H. Zhang, X. Chai, Y. Chen and R. Sun, J. Solid State Chem., 2008, 181, 3327-3336.

46 T. G. Appleton, H. C. Clark and L. E. Manzer, Coord. Chem. Rev., 1973, 10, 335-422.

47 C. Ruiz-Perez, P. A. L. Luis, F. Lloret and M. Julve, Inorg. Chim. Acta, 2002, 336, 131-136.

48 S. Stoll and A. Schweiger, J. Magn. Reson., 2006, 178, 42-55. 49 O. Kahn, Molecular Magnetism, VCH Publishers, Inc., 1993.

50 A. Carrington and A. D. McLachlan, Introduction to Magnetic Resonance, Harper and Row, New York, 1967.

51 D. Žilić, K. Molčanov, M. Jurić, J. Habjanič, B. Rakvin, Y. Krupskaya, V. Kataev, S. Wurmehl and B. Büchner, Polyhedron, 2017, 126, 120-126.

52 B. Szymańska, D. Skrzypek, D. Kovala-Demertzi, M. Staninska and M. A. Demertzis, Spectrochim. Acta, Part A, 2006, 63(3), 518-523.

53 J.-S. Park, T.-J. Park, K.-H. Kim, K. Oh, M.-S. Seo, H.-I. Lee, M.-J. Jun, W. Nam and K.-M. Kim, Bull. Korean Chem. Soc., 2006, 27, 193-194.

54 E. Fischer, Ber. Dtsch. Chem. Ges., 1903, 36, 2982-2992.

55 G. R. Eaton, S. S. Eaton, D. P. Barr and R. T. Weber, Quantitative EPR, Springer, Vienna, 2010.

56 CrysAlisPro Software System, Version 1.171.38.41, Rigaku Oxford Diffraction, 2015.

57 L. J. Farrugia, J. Appl. Crystallogr., 2012, 45, 849-854.

58 G. M. Sheldrick, Acta Crystallogr., Sect. A: Found. Crystallogr., 2008, 64, 112-122.

59 G. M. Sheldrick, Acta Crystallogr., Sect. C: Struct. Chem., 2015, 71, 3-8.

60 A. L. Spek, Acta Crystallogr., Sect. D: Biol. Crystallogr., 2009, 65, 148-155.

61 C. F. Macrae, I. J. Bruno, J. A. Chisholm, P. R. Edgington, P. McCabe, E. Pidcock, L. Rodriguez-Monge, R. Taylor, M. Towler, J. van de Streek and P. A. Wood, J. Appl. Crystallogr., 2008, 41, 466-470. 